\title{
56
}

\author{
Victor KOZYUK
}

\section{MACROPRUDENTIAL REGULATION IN COUNTRIES OF CENTRAL AND EASTERN EUROPE: EXPERIENCE OF FINANCIAL IMBALANCES, PROACTIVITY OR PROTECTIVE REACTION}

\begin{abstract}
Is experience of financial imbalances driving intensity of macroprudential policy instruments use? Theoretically - yes, because they support to diminish conflict between price, exchange rate and financial stability. In the same time CEE countries demonstrate more complicated picture. Such countries experienced strong structural determined vulnerability to financial imbalances accumulation. The scale of correction of such imbalances also was tremendous. But empirical analysis doesn't show that experience of imbalances is a driving force of more intensive use of macroprudential policy instruments. Results of regression analysis based on 18 CEE countries shows that such countries are likely to divide on two groups: those there macroprudential policy is complimenting active structural reforming, and those there such policy is looked like defense reaction on challenges related to general structural weakness.
\end{abstract}

(C) Victor Kozyuk, 2018.

Kozyuk Victor, Dr. of Econ. Sciences, Professor, Ternopil National Economical University, Ukraine. 


\section{Key words:}

CEE countries, macro-prudential policy, financial imbalances, proactivity.

JEL: E02, H3.

\section{Macroprudential regulation in the banking management system}

The countries of Central and Eastern Europe approaching the qualitative characteristics of the EU, or in other words institutional convergence, can be considered a powerful factor in structural reforms. Competitive pressure, on the one hand, and on the other hand - the attempt to compensate for the growing fiscal burden in conjunction with the increase in the cost of labour have been peculiar drivers of reforms for a long time. Improving the quality of governance and the general «maturing» of macroeconomic management in the eastern region of the EU is often perceived as something par for the course. It is no coincidence that although the Baltic countries underwent shock reforms to correct the financial imbalances caused by the crisis and Slovenia experienced financial stress, most CEE countries went through the global shock wave of 2007-2009 relatively smoothly. Certainly, for Ukraine, as well as for a number of other countries, the global crisis will remain a line in the sand between the trajectories of welfare improvement for a long time. However, in key Eastern EU countries - Poland, Slovakia, Czech Republic, Hungary, Romania, Bulgaria, Slovenia, etc. - the issue of adjusting to post-crisis reality is characterized by further emphasis on building institutions and improving the efficiency of the macro financial stability framework.

The global trend towards distinguishing a separate line of financial stability policy - macro-prudential regulation - clearly formed in the post-crisis conditions. The traditional division into monetary policy and microprudential regulation was based on a series of theoretical imprints that were associated with the new Keynesian approach to macroeconomics and the neoclassical approach to the regulation of the financial sector. It presumed that markets are effective; transparency improves the effectiveness of allocation processes; long-term deviation of prices from equilibrium in the market is impossible; and the behaviour of par- 

experience of financial imbalances, proactivity or protective reaction

ticipants is rational, etc. However, there is a conceptual difference between macro- and micro-prudential approaches (Table 1), which follows from theoretical ideas about the nature of financial stability. The spread of the macro-financial perspective on the design of macro politics, relevant to the growing importance of the financial sector in the economy, brought about significant changes in the structuring of tools aimed at ensuring financial stability. The principle «price stability is equivalent to financial stability» has been rethought, although the debate about the ratio of monetary and macroprudential policy contributions to ensuring financial stability and, accordingly, their areas of responsibility only intensifies.

Table 1

Comparison of macro- and microprudential perspectives

\begin{tabular}{|c|c|c|}
\hline & Macroprudential & Microprudential \\
\hline Proximate objective & $\begin{array}{l}\text { Limit financial system- } \\
\text { wide distress }\end{array}$ & $\begin{array}{l}\text { Limit distress of individual } \\
\text { institutions }\end{array}$ \\
\hline Ultimate objective & Avoid output (GDP) costs & $\begin{array}{c}\text { Consumer } \\
\text { (investor/depositor) } \\
\text { protection }\end{array}$ \\
\hline Model of Risk & (in part) endogenous & Exogenous \\
\hline $\begin{array}{l}\text { Correlations and com- } \\
\text { mon exposures across } \\
\text { institutions }\end{array}$ & Important & Irrelevant \\
\hline $\begin{array}{l}\text { Calibration of pruden- } \\
\text { tial controls }\end{array}$ & $\begin{array}{l}\text { In terms of system-wide } \\
\text { distress; top-down }\end{array}$ & $\begin{array}{l}\text { In terms of risks of individ- } \\
\text { ual institutions; bottom-up }\end{array}$ \\
\hline
\end{tabular}

Source: Borio, C. Towards a Macroprudential Framework for Financial Supervision and Regulation? / C. Borio // BIS Working Paper. - 2003. № 128. P. 2.

European Systemic Risk Board, an agency charged with monitoring the systemic vulnerability, was created in the EU to oversee changes in the nature of financial stability policy. Similar bodies were created in a number of other countries. In addition, the framework for macroeconomic policy in the EU-EMU has undergone significant changes after the global and debt crisis of 2008-2010. If before, the Maastricht convergence criteria, supplemented by the Stability and Growth Pact were the basis for the euro zone macroeconomic framework, reforms in the EU-EMU significantly changed this model and introduced a macrofinancial block. Thus, the macrofinancial component was practically erased from the design of the pre-crisis macro policy. However, such a statement can only be expressed now, in light of new knowledge about the role of the financial factor in 
generating macroeconomic instability. Accordingly, the pre-crisis scheme envisaged several significant moments. Firstly, financial stability lay within the scope of national responsibility. Secondly, national financial stability was ensured by the sound fundamentals for macroeconomic policies (central bank independence, quantitative targets for inflation, restrictions on budget deficit and public debt), and micro-prudential regulation. The latter had to be sufficiently effective in achieving the threshold quality of the institutions that made EU membership possible at all. Thirdly, the no bail-out principle meant that the country could not rely on any assistance from the Union level or collective participation in the settlement of financial problems.

A number of innovations that radically changed macroeconomic management in the EU-EMU supplemented the post-crisis design. Firstly, the Stability and Growth Pact was reformed towards increasing fiscal responsibility. Secondly, the European stabilization mechanism was introduced, addressing the systemic vulnerability of countries that lost access to liquidity. Thirdly, the European mechanism for monitoring economic imbalances and a set of quantitative indicators was introduced, exceeding which necessitated correction of the macroeconomic course of the country and activation of a number of structural changes. Fourthly, within the framework of the European Banking Union, macroprudential regulation was implemented, while whilst transitioning to Basel III, microprudential regulation received a significant impetus to focus on the risks of pro-cyclicality and systemic vulnerability. At the same time, the development of macroprudential policies at the national level is welcomed both in Brussels and in Frankfurt am Main.

Nevertheless, the debate on the European Banking Union clearly stated that the quality of the institutions continues to be a significant obstacle to further financial integration in Europe. The institutional coherence of the EU was clearly overestimated, and the North-South division continues to be an irritating factor limiting the progress towards a more complete economic union. In this context, most CEE countries often show better results than some «original» members do. At least the West-East heterogeneity of the EU was never up for debate in the new macroeconomic scheme of the EU-EMU. The problem of the persisting gap in the development levels and GDP per person was much more urgent. In other words, slow real convergence generates the risk of slowing down functional convergence, and the convergence of institutions' quality may remain vulnerable to sources of investing into such quality. Structural reforms aimed at enhancing macrofinancial stability may reflect the maintenance of a significant difference in the profiles of financial systems. This does not mean that the quality of institutions is pushed to the background. The optimal mix policy addressing macrofinancial stability would differ sufficiently from country to country, not so much on the grounds of introducing new regulatory approaches, as on the basis of the level at which regulation would be carried out. Prerequisites for this may be due to differences in the structure of the financial sector. The asymmetries of membership in the euro zone and in the European Banking Union make it possible. 

experience of financial imbalances, proactivity or protective reaction

This, in turn, raises the question of the optimal balance of monetary, macro- and microprudential policy, given that monetary regimes themselves determine the risks that the country will be vulnerable to, as well as the nature of adaptation to the new equilibrium conditions.

Despite the rather evident changes in the macroeconomic policy transformation vector, the CEE countries differ on the search for the best options for ensuring financial stability. This is largely due to the fact that the region continues to remain varied in terms of monetary regimes. Asymmetric membership in the European Banking Union can also play its part in this (such membership is mandatory for member countries of the euro zone and for other EU member states is voluntary). Just as the lack of a theoretical consensus on the optimal mix-policy of macro-financial stability can be a peculiar answer to the question of why the advancement of the doctrine of macroprudential regulation finds a cautious response in a region that will remain structurally vulnerable to the systemic financial risks for a long time to come. Despite the lack of a theoretical consensus on the optimal combination of monetary and macroprudential policies, including the corresponding institutional design, the issue of drivers for the transition to a new modality of financial stability policy in the region continues to be relevant. Rather, further changes in monetary regimes in the new EU member countries will not happen soon. This paves the way for further discussions on the role of macroprudential policy in the countries facing the process of real convergence and potentially exposed the problem of financial imbalances.

In light of the evolving theoretical basis of the macroprudential approach ${ }^{1}$, most studies of macroeconomic policies of the CEE countries before the global financial crisis were focused on one issue. The issue was how to ensure financial stability in a country that is strongly influenced by real convergence, is attractive to capital inflows, but rather limited in its ability to significantly increase its exchange rate without jeopardizing national competitiveness and worsening the balance of payments, the current account of which is largely in deficit ${ }^{2}$. In particular, most works devoted to this problem focus on the potential conflict of fulfilling the criteria of the euro-convergence in conditions of capital inflows, the effect of

\footnotetext{
${ }^{1}$ Borio, C. Whither Monetary and Financial Stability? The Implications of Evolving Policy Regims / C. Borio, W. White // BIS Working Paper. - 2004. - № 147. - P. 1-51; Borio C. Monetary and Prudential Policies at a Crossroads? New Challenges in the New Century / C. Borio // BIS Working Paper. - 2006. - № 193. - P. 2-28.

${ }^{2}$ Masson, P. Monetary and Exchange Rate Policy of Transition Economies of Central and Eastern Europe after the Launch of EMU / P. Masson // IMF Policy Discussion Paper. 1999. - PDP/99/4. - P. 1-25; Corker R. Exchange Rates Regimes in Selected Advanced Transition Economies - Coping with Transition, Capital Inflows, and EU Accession / R. Corker, C. Beaumont, R. van Elkan, D. Jakova // IMF Policy Discussion Paper. 2000. - PDP/00/3. - P. 1-25.
} 
the Balassa-Samuelson effect and the need for continued disinflation ${ }^{3}$. On the one hand, we can see the problem of «real vs nominal convergence» ${ }^{4}$. On the other hand, a number of structural features of the Eastern EU countries point out that they are extremely vulnerable to the transition of currency crises into financial ones. Membership in the euro area can help resolve the dilemma of how to ensure financial stability in a situation where there is obvious conflict between exchange rate and price stability ${ }^{5}$. Such a research focus was largely driven by the experience of the Asian crisis, or in the wider sense, the turmoil of 19962002 , when the reversals of capital flows and the first steps toward financial integration generated stress in the currency market. Such a «post-Asian» view of financial stability was virtually inseparable from the reflections on the fact that the absence of a conflict between inflationary and exchange rate goals is the best macroeconomic contribution to maintaining a healthy tone of the financial sector.

After the global financial crisis, the situation has changed. Some postsocialist countries in Europe have shown typical signs of a financial imbalances spiral and not merely reflect the conflict between inflationary and exchange rate goals; that global financial integration can create the illusion of a real convergence facilitator. The monetary regime is not, in fact, neutral to how global liquidity expansion generates a boom in the asset market, nurtures domestic credit, and, ultimately, worsens the balance of payments in connection with the procyclical influx of capital inflating into consumption. According to A. Aslund, precisely the polar monetary regimes before the global financial crisis caused the dramatic differences in the appearance of macrofinancial vulnerability, laying the groundwork for further differences in the economic policy trajectories. At the same time, the successes of the first decade of market transformation did not mean immunity from the vulnerability to financial imbalances ${ }^{6}$.

It can be argued that the experience of the EMU crisis has also contributed to rethinking the causes of macro-financial vulnerabilities in the CEE countries. In

\footnotetext{
${ }^{3}$ Kenen, P. EU Accession and the Euro: Close Together or Far Apart? / P. Kenen, E. Meade // Institute for International Economics Policy Briefs. - 2003. - № PB03-9. P. 1-19; Fidrmuc J. Increasing Integration of Applicant Countries into International Financial Markets: Implications for Monetary and Financial Stability / J. Fidrmuc, F. Schardax // Currency Areas and the Use of Foreign Currencies. - BIS Paper. - 2003. - № 17. P. 92-109; Begg D. Accession Countries Face Increased Instability in ERM II / D. Begg, B. Eichengreen, L. Halpern, J. von Hagen, Ch. Wyplosz // CEPR Policy Paper. - 2005. № 10.

${ }^{4}$ Natalucci, F. The Road to Adopting the Euro: Monetary Policy and Exchange Rate Regimes in the EU Candidate Countries / F. Natalucci, F. Ravenna // Board of Governors of the Federal Reserve System International Finance Discussion Papers. - 2002. - № 741. P. 1-45.

${ }^{5}$ The Role of National Bank of Poland in the Process of European Integration. - Warsaw : National Bank of Poland, 2003. - 55 p.

${ }^{6}$ Aslund, A. The Last Shall Be the First: The East European Financial Crisis / A. Aslund. Wash. (D. C.) : PIIE, 2011. - 212 p.
} 

experience of financial imbalances, proactivity or protective reaction

light of the critical developments in the euro area during 2009-2011, attention was drawn to a number of points. Intra-European imbalances have evolved by the North-South division, so re-estimating the expectations of persistent income growth should be perceived as an important component of the monetary vulnerability mechanism of the monetary union. Asymmetry in the real effective exchange rate paths has shown not only the potential competitiveness gaps, but also apparent structural inconsistencies between labour markets and competitive pressure. This pressure was easily concealed by the fact that the current account deficit was covered by capital inflows. Most succinctly, this problem can be expressed as follows: real convergence, maintaining competitiveness and the rapid accumulation of private (and, of course, public) debts may be incompatible with each other, especially in the absence of centralized emergency liquidity supply mechanisms. Correction of imbalances can be painful, requiring significant internal devaluation (the option of changing the exchange rate is blocked through membership in the currency union), while the process of de-leveraging limits the potential for economic recovery ${ }^{7}$.

It is easy to see that the theoretical foundations of macroprudential regulation resonate best with this view on systemic financial vulnerability. Actually, this very approach made it possible to move away from the «post-Asian» view on the risks of financial instability in the region and recognize the same makers of macro-financial instability, which led to the divergence of the euro zone and virtually raised the question of its future, in the post-socialist countries of the EU. One could even say that the lack of guarantees for macro-financial stability in the monetary union for the countries of real convergence has prompted a sceptical view of future membership in the EMU of countries like Poland, Hungary or the Czech Republic. Thus, most researchers point out that the region continues to display a number of structural features that are more likely to be catalysts rather than inhibitors of macro-financial vulnerability.

First, unlike many emerging markets, CEE countries have long remained largely net recipients of capital ${ }^{\text {. }}$. For a long time significant payment deficits were covered by the inflow of FDI, and after the global financial crisis the dependence on capital inflows did not weaken, but rather intensified. Even with a certain cor-

\footnotetext{
${ }^{7}$ This problem is presented in a number of our works in more detail: Козюк В. В. Теоретичний вимір макрофрінансових ризиків дивергенції євро зони / В. В. Козюк // Економічна теорія. - 2011. - № 3. - С. 59-72; Козюк В. В. Теорія оптимальних валютних зон у світлі глобальної фрінансової кризи і ризиків дивергенції $€$ СС / В. В. Козюк // Економічна теорія. - 2012. - № 4. - С. 56-71; Козюк В. В. Глибина корекції фрінансових дисбалансів у зоні євро та проблема відновлення зростання / В. В. Козюк // Журнал європейської економіки. - 2017. - Т. 16, № 1. - С. 17-40.

${ }^{8}$ Abiad, A. International Finance and Income Convergence: Europe is Different / A. Abiad, D. Leigh, A. Mody // IMF Working Paper. - 2007. - WP/07/64. - P. 1-36; Pipat L. Do Economists' and Financial Markets' Perspectives on the New Members of the EU Differ? / L. Pipat, S. Schandler // IMF Working Paper. - 2007. - WP/07/65. - P. 1-31.
} 
rection of current accounts (in some cases, substantial), the vulnerability to fluctuating global capital flows persists, in particular due to the increase in external debt in the private sector. The impetus to increase such debt, of course, was present even before 2008, pointing out a potential source of vulnerability 9 . However, after the crisis, large-scale deleveraging has mostly bypassed the CEE countries, making borrowers' financial sustainability sensitive to volatile capital flows. Asymmetric waves of unconventional monetary practices by the Fed and the ECB add to the expectations of the ability to withstand the cyclical flows of global capital.

Secondly, the pro-cyclical nature of capital flows in the case of CEE countries that remain vulnerable to the narrowing of net inflows has largely impacted domestic prices of assets and lending rather quickly, reminiscent of the typical problem of financial imbalances in the euro area. However, unlike its members, post-socialist countries have faced another vulnerability modality, as well as a wider set of macroeconomic adaptation options. The overheating of the financial sector and the boom in consumption have highlighted the conflict between maintaining long-term competitiveness and the elastic response of financial aggregates to pro-cyclical inflows of capital. In the case of the Baltic States and Bulgaria, as well as Slovenia and Slovakia, the situation did not differ much from the Southern EMU and Ireland, but in the case of Poland, the Czech Republic and Hungary, the modalities of vulnerability looked more complex. On the one hand, the fluctuations of the exchange rate allow smoothing the shocks of capital flows and preserving the channel of external competitiveness adaptation. On the other hand, a strong trend towards increasing the rate encourages additional external borrowing or dollarization. The financial channel of the exchange rate turned out to be a real problem for the big Eastern European countries, creating the way to reformat the mix policy by introducing an additional instrument. The floating rate has shown vulnerability to the strong tendency towards risk taking, thus pointing to the common vulnerability of the region to global financial imbalances ${ }^{10}$.

Thirdly, real convergence and concomitant increases in the real exchange rate, if they are perceived as an equilibrium trend, increase the effect of the exchange rate tool, as they make the interrelations between variables and expectations of economic agents fundamental. This opens the way for expectations to become a key element of the capitalizing foreign currency borrowing. The extent

\footnotetext{
${ }^{9}$ Goldstein, M. What the Next Emerging-Market Financial Crisis Look Like? / M. Goldstein // IIE Working Paper. - 2005. - № 05-7. - P. 1-115.

${ }^{10}$ Cecchetti, S. Monetary Policy and Financial Stability: What's Ahead for Central and Eastern European Countries / S. Cecchetti // BIS Speeches. - 2010. - P. 1-11; Waysand C. European Financial Linkages: A New Look at Imbalances / C. Waysand, K. Ross, J. de Guzman // IMF Working Paper. - 2007. - WP/10/295. - P. 1-61; BrzozaBrzezina M. Can We Prevent Boom-Bust Cycles During Euro Area Accession? / M. Brzoza-Brzezina, P. Jacquinot, M. Kolasa // ECB Working Paper. - 2010. - № 1280. P. 1-47.
} 

experience of financial imbalances, proactivity or protective reaction

to which regulators will be able to prevent the immediate increase of external debt by the private sector and the deterioration of competitiveness will pre-empt the weakening of the link between exchange rate and financial stability, as well as between financial vulnerability and the ability to maintain a steady rate of economic growth. In terms of optimal mix policy, this urges a number of researchers to emphasize the growing role of the fiscal factor in neutralizing the cyclical reaction of investment and consumption to the inflow of capital, on the one hand, and to an increase in the exchange rate, on the other hand ${ }^{11}$. In turn, the very differences in fiscal policy were perhaps the main criterion for the differentiation of a number of CEE countries in terms of their vulnerability to volatile capital flows, the magnitude of imbalances and the depth of the necessary correction ${ }^{12}$.

Departing from discussing the role of fiscal policy in ensuring macrofinancial stability, one can see that the typical modality of systemic vulnerability of the CEE countries is an invitation to introduce an economic policy instrument whose profile would help to eliminate the conflict between price, exchange rate and financial stability. Researchers who focus on the links between exchange rate changes, capital flows, competitiveness, inflation, and systemic financial sustainability are virtually unanimous about the fact that macroprudential regulation can fill the gap in mixed politics ${ }^{13}$.

Thus, it is clear that the CEE countries should actively develop this type of financial stability policy, which makes it important to study the practices and effectiveness of macroprudential regulation. The basic schemes for the introduction and implementation of the macroprudential approach are well studied ${ }^{14}$, and the level of their structuring actually corresponds to stereotypical «road maps» in implementation in different countries. In particular, the question of the taxonomy of macroprudential instruments (see Table 2), transmission links, the institutional design of the policy, etc., is largely the subject of theoretical consensus. However, the issue of optimal coordination between monetary and macroprudential policies, the boundaries between the latter and the policy on capital flows, etc.,

\footnotetext{
${ }^{11}$ Brzoza-Brzezina, M.Can We Prevent Boom-Bust Cycles During Euro Area Accession? / M. Brzoza-Brzezina, P. Jacquinot, M. Kolasa // ECB Working Paper. - 2010. - № 1280. P. 1-47.

12 Cocozza, E. The Impact of Global Crisis on South-Eastern Europe / E. Cocozza, A. Colabella, F. Spadafora // IMF Working Paper. - 2011. - WP/11/300. - P. 1-70.

${ }^{13}$ IMF-FSB-BIS. (2016). Elements of Effective Macroprudential Policies. Lessons from International Expirience. 26 August 2016. - P. 1-22; Gulcin Ozkan F. On the Use of Monetary and Macroprudential Policies for Small Open Economies / F. Ozkan Gulcin, D. Unsal Filiz // IMF Working Paper. - 2014. - WP/14/112. - P. 1-26; Turner Ph. Macroprudential Policies, the Long-term Interest Rate and the Exchange Rate / Ph. Turner // BIS Working Paper. - 2016. - № 588. - P. 1-23.

${ }^{14}$ Claessens, S. An Overview of Macroprudential Policy Tools / S. Claessens // IMF Working Paper. - 2014. - WP/14/214. - P. 37.
} 
continue to be actively debated ${ }^{15}$. Thus, we can make some generalizations regarding the analysis of the macroprudential regulation effectiveness, despite the relatively short time of its implementation.

Table 2

\section{Macroprudential tools}

\begin{tabular}{|c|l|l|}
\hline & \multicolumn{1}{|c|}{ Time dimension } & \multicolumn{1}{c|}{ Sectoral dimension } \\
\hline Capital & $\begin{array}{l}\text { Countercyclical capital buffer } \\
\text { Dynamic provisioning } \\
\text { Sectoral capital requirements } \\
\text { Sectoral approach to weighing } \\
\text { risks } \\
\text { Countercyclical leverage re- } \\
\text { quirements }\end{array}$ & $\begin{array}{l}\text { System risk buffers (SRB) } \\
\text { Capital buffers of systemically } \\
\text { important institutions }\end{array}$ \\
\hline \multirow{5}{*}{ Assets } & $\begin{array}{l}\text { Loan-to-value cap (LTV) } \\
\text { Loan-to-income cap (LTI) } \\
\text { Debt-to-income cap (DTI) }\end{array}$ & $\begin{array}{l}\text { Restrictions on transactions } \\
\text { with a counter-agent (concen- } \\
\text { tration limits) } \\
\text { Restricting a significant open } \\
\text { position }\end{array}$ \\
\hline \multirow{5}{*}{ Liquidity } & $\begin{array}{l}\text { Requirements for deposit-to- } \\
\text { loan coverage } \\
\text { Time-varying requirements for } \\
\text { liquidity indicators } \\
\text { Time-varying requirements for } \\
\text { collateral in marginal lending }\end{array}$ & $\begin{array}{l}\text { Liquidity coverage ratio (LCR) } \\
\text { Net stable funding ratio (NSFR) } \\
\text { Minimum haircuts / margin } \\
\text { floors } \\
\text { Minimal reserve requirements }\end{array}$ \\
\hline
\end{tabular}

First, in general macroprudential instruments achieve the goals of limiting the growth of variables, which are associated with some form of financial instability or vulnerability of a particular financial system segment. Secondly, the level of financial development significantly affects the ability of regulators to control the behaviour of domestic credit. In other words, the less developed the financial

${ }^{15}$ IMF-FSB-BIS. (2016). Elements of Effective Macroprudential Policies. Lessons from International Experience. 26 August 2016. - P. 1-22; IMF. Key Aspects of Macroprudential Policy - Background Paper // IMF Policy Paper. - 2013. - June. - P. 1-68; IMF. Key Aspects of Macroprudential Policy // IMF Policy Paper. - 2013. - June. - P. 1-56; IMF. The Interaction of Monetary and Macroprudential Policy // IMF Policy paper. - 2013. - January. - P. 1-48; CGFS. Macroprudential Instruments and Frameworks: A Stocktaking of Issues and Experience // CGFS Paper. - 2010. -№ 38 (Basel: BIS). - P. 1-46. 

experience of financial imbalances, proactivity or protective reaction

market and the weaker the global financial integration of the country, the more effective the instruments are. Thirdly, the ability of the macroprudential policy to neutralize the pro-cyclical effects of capital flows is asymmetric. Such tools limit the heating of the financial sector in the boom phase quite well, but they are not able to significantly prevent credit shrinkage during a recession. Nevertheless, their ability to weaken the unfavourable link between the movement of exchange rates and capital flows is traced especially easily in emerging markets. Fourthly, these tools are most effective in dealing with imbalances in the real estate market, given the precise possibilities of a focal impact on lenders and borrowers. The ability of capital buffers to significantly restrict the cumulative expansion of the financial sector can be attributed to more direct instruments, such as the restrictions on leverage. Fifth, the ability to neutralize concentration risks allows a flexible response to the various structural features of countries. The pronounced raw material sector amplifying the sensitivity of capital flows and shocks to trading conditions is generally considered the addressee of macroprudential interference $^{16}$. Although this is not so relevant for the CEE countries, the shock of trade conditions cannot always be effectively neutralized without additional social losses.

Thematic study of the changes in the policy of financial stability in CEE in recent times has not been limited ${ }^{19}$. However, there are quite few subject studies on the intensity of the macroprudential instruments use. For example, a number of regularities have been identified which confirm the results of previous works in the cases of Bulgaria, Croatia, Romania and Serbia. In particular, exceptionally strong measures make it possible to limit unwanted expansion of foreign currency loans (either in the form of dollarized loans from local banks, or in the form of external corporate borrowings). Secondly, possibilities of external borrowing significantly reduce the effectiveness of the measures applied to the domestic loans. Thirdly, only a set of macro-prudential instruments, rather than the use of individual ones, can prevent a credit boom, etc. ${ }^{18}$

\footnotetext{
${ }^{16}$ Cerutti, E. Changes in Prudential Policy Instruments - A New Cross-Country Database / E. Cerutti, R. Correa, E. Fiorentino, E. Segalla // IMF Working Paper. - 2016. WP/16/110. - P. 1-23; Bruno V. Comparative Assessment of Macroprudential Policies / V. Bruno, I. Shim, H. Shin Song // BIS Working Paper. - 2015. - № 502. - P. 1-56; Cerutti E. The Use and Effectiveness of Macroprudential Policies: New Evidence / E. Cerutti, S. Claessens, L. Laeven // IMF Working Paper. - 2015. - WP/15/61. - P. 1-36; Carreras O. Macroprudential Tools, Transmission and Modelling/ O. Carreras, Ph. Davis, R. Piggot // Firstrun Deliverable. - 2016. № 4.7. - P. 1-57; Cizel J. Effective Macroprudential Policy: Cross-Sectors Substitution from Price and Quantity Measures / J. Cizel, J. Frost, A. Houben, P. Wierts // IMF Working Paper. - 2016. - WP/16/94. P. 1-47.

${ }_{17}$ Miklaszewska, E. The Consequences of Post-Crisis Regulatory Architecture for Banks in Central and Eastern Europe / E. Miklaszewska, K. Mikolajczyk, M. Pawlowska // NBP Working Paper. - 2012. - № 131. P. 1-35.

18 Dimova, D. Macroprudential Policies in Southeastern Europe/ D. Dimova, P. Kongsamut, J. Vandenbussche // IMF Working Paper. - 2016. - WP/16/29. P. 1-81.
} 
The analysis of a wider sample of CEE countries within the framework of the 24 EU countries (Bulgaria, Croatia, Czech Republic, Estonia, Hungary, Latvia, Lithuania, Poland, Romania, Slovakia, Slovenia and Serbia) presented the following results. The propensity for intensive use of macroprudential instruments is determined by the level of development of the country (the poorer the country, the more likely the active use), the development of the financial sector (similar correlation), general macroeconomic instability, openness to capital flows. At the same time, the less flexible exchange rate, level of dollarization and lesser presence of foreign banks positively correlate with the variable describing the intensity of the macroprudential instruments use. In other words, the CEE countries, being specifically vulnerable to systemic financial stress, exhibit a significant number of differences in the macroeconomic and structural trajectories that determine the variation in the intensity of the macroprudential instruments use. However, where they are used, the results coincide with the overall logic of macrofinancial analysis. In addition, in the cases when such instruments were used more intensively before the crisis, the fiscal losses associated with the salvation of the financial sector, the extent of the provided liquidity and, as a result, the amount of non-working loans amounted to less ${ }^{19}$. Here the indicator of intensity was a variable, which was the result of quantifying the results of the central banks polls ${ }^{20}$. As in other countries, the effectiveness of macroprudential regulators in the CEE was most apparent on the mortgage market. However, the possibility of smoothing fluctuations in real estate prices remained sensitive to the exchange rate regime. The price boom before the crisis and the deep fall after 2008 are more typical for Bulgaria than for Poland, the Czech Republic or Romania ${ }^{21}$.

From the aforementioned studies addressed to macroprudential policy in the new EU member states, it is evident that the use of relevant instruments is rather intensive and diverse. An alternative approach to determining the intensity of using macroprudential levers - calculation of the macroprudential policy index - does not prove the credible leadership of the EU countries of the Central East $^{22}$. Naturally, differences in the estimation of such intensity can affect the

\footnotetext{
19 Dumicic, M. Macroprudential Policy in Central and Eastern European Countries - Is There Something We Should Learn? / M. Dumicic // The Twentieth Dubrovnik Economic Conference, Dubrovnik, June 11-13, 2014. Organized by Croatian National Bank. - Dubrovnik, 2014. - P. 1-50; Dumicic M. Effectiveness of Macroprudential Policies in Central and Eastern European Countries / M. Dumicic // Croatian National Bank Working Paper. 2017. - W-48. - P. 1-27.

20 Lim, C. Macroprudential Policy: What Instruments and How to Use Them? Lessons from Country Experience / C. Lim, F. Columba, A. Costa [et al.] // IMF Working Paper. 2011. - WP/11/238. - P. 1-81.

${ }^{21}$ Donath, L. Financial Cycles and Macroprudential Intervention in Selected Central and Eastern European Countries / L. Donath, V. Mihutescu, I. Oprea // West University of Timisoara. - 2015. - Oct. - P. 1-13.

${ }_{22}$ Cerutti, E. The Use and Effectiveness of Macroprudential Policies: New Evidence /

E. Cerutti, S. Claessens, L. Laeven // IMF Working Paper. - 2015. - WP/15/61. - P. 1-36.
} 

experience of financial imbalances, proactivity or protective reaction

connection between driver variables and policy results. The size and composition of the sample are equally important. The inclusion of CEE countries in the sample along with the countries of the euro area may distort the results, given that some of the latter have demonstrated a much greater vulnerability to the spiralling financial imbalances. This raises the question of a clearer focus on the postsocialist region. In addition, even if the revealed dependencies point to the inverse relationship between the level of development (the variable of GDP per capita) and the intensity of the macroprudential tools use, they describe the different vulnerability modalities that trigger differences in the mix policy more than they explain the drivers of such use. A sample from more homogeneous countries can give less obvious results, for example, in terms of link density. Similarly, if the levels of dollarization, credit depth, capital flows are perceived as drivers of the corresponding intensity, the emphasis is not only on structural characteristics, but also on the experience ${ }^{23}$. This raises the question of possibly expanding the set of variables or combining them with variables that describe, for example, the correction of financial imbalances. In addition to the actual financial openness, the nature of constraints on capital flows is also important, which, in combination with the exchange rate regime, determines the elasticity of the link between the internal financial cycle and the so-called global financial cycle ${ }^{24}$. Moreover, comparing the financial imbalances of the CEE countries with those of the euro area member-states would allow us to understand whether the imbalance factor and its correction can be considered a driving force for the expansion of the mix policy through macroprudential regulation.

On the other hand, we cannot deny that euro area membership of Slovenia, Slovakia and the Baltic countries, as well as the success of inflation targeting in the Czech Republic and Poland, generate different ideas about the best policy of financial stability. Fiscal policy can also play an important role here. For example, in the case of its calibration to counter-cyclical needs, the macroprudential policy aimed at weakening the pro-cyclicality of the financial system may be inactive or poorly articulated. In other words, the common structural characteristics can determine the common elements of constructing policy tools addressing vulnerabilities generated by such characteristics. However, if the similarities in policy cannot be traced, they can be considered a manifestation of countrypreferences regarding the implementation of a policy. Differences in the estimates of the intensity of introducing macroprudential instruments likely indicate

\footnotetext{
${ }^{23}$ In this context see the description of the independent variables in: Dumicic M. Macroprudential Policy in Central and Eastern European Countries - Is There Something We Should Learn? / M. Dumicic // The Twentieth Dubrovnik Economic Conference, Dubrovnik, June 11-13, 2014. Organized by Croatian National Bank.. - Dubrovnik, 2014. - P. 1-50.

${ }^{24}$ Empirical assessments of such relationships indicate that the exchange rate regime and capital flows remain relevant to the nature of the transmission of global macrofinancial shocks. See: Aizenman J. Monetary Policy Spillovers and the Trilemma in the New Normal: Periphery Country Sensitivity to Core Country Conditions / J. Aizenman, M. Chinn, H. Ito // NBER Working Paper. - 2015. - № 21128. - P. 1-49.
} 
the probability that the principle of idiosyncrasy dominates the principle of structural similarity, generating similar preferences in the application of certain policy tools. This requires focusing on drivers of macroprudential solutions in CEE countries in terms of the experience in correcting the financial imbalances.

\section{Financial imbalances in CEE countries: theoretical reservations, empirical facts, and correctional nature}

The way in which internal and external financial imbalances relate to one another, in many ways sheds light on the problem of systemic vulnerability in the country. The very nature of the connection between them can vary in the context of countries, but the fact remains: they amplify each other. The higher propensity to either internal or external imbalances is, of course, determined by the structural features of the economy, in particular, how it is positioned in terms of global trade and financial flows. An equally important factor is the mode of monetary and fiscal policy. One or another mode can significantly weaken the elasticity of the spiralling imbalances, especially in cases where the latter are extremely sensitive to globally centric drivers. It is no coincidence that the development of the macroprudential approach was conceptualized because of the problem of linking internal and external imbalances. The introduction of macroprudential instruments is intended to neutralize the ease with which such imbalances are mutually supported for levelling the systemic vulnerability of the financial sector and narrow the scope of the economy's vulnerability to financial shocks.

In the theoretical terms, the mutual amplification of imbalances follows from such facts ${ }^{25}$. First, development of the financial sector makes it more receptive to expansion drivers. Typically, such expansion is associated with liquidity. Its main drivers are: leading central banks lowering/maintaining interest rates at a low level for a long time; financial innovations that make the creation of solvency units more rapid and that enable easing the rigid budget restrictions; increased cross-border activity of financial companies; changes in the legal environment.

The focus of central banks on price stability leads to the fact that under conditions of positive performance shock monetary policy may be adequate in the vein of traditional New-Keynesian approach, but excessively soft in terms of the «new environment» approach. The same applies to the problem of oil

\footnotetext{
${ }^{25}$ Borio C. Whither Monetary and Financial Stability? The Implications of Evolving Policy Regims / C. Borio, W. White // BIS Working Paper. - 2004. - № 147. - P. 1-51; Borio C. Monetary and Prudential Policies at a Crossroads? New Challenges in the New Century / C. Borio // BIS Working Paper. - 2006. - № 193. - P. 2-28.
} 

experience of financial imbalances, proactivity or protective reaction

shocks. The weakening link between raw material prices and consumer price inflation can increase the pressure on oil prices to rise not so much because of the fundamental market factors, but rather because of the rising aggregate demand not controlled by central banks, which do not necessarily have to respond to oil shock by raising rates. The emergence of high financial system elasticity and the increasing importance of financial assets in the behaviour of economic agents make demand more sensitive to new opportunities for access to solvency units generated in the financial sector. This creates additional opportunities for smoothing out the consumption and investments, but does not mean smoother issue, expanding the amplitude of adaptive responses of the current account.

Secondly, capital flows clearly signal the state of global liquidity, and any opportunities at the level of an individual country quickly become the basis for a massive influx. This, in turn, makes it possible to improve access to finance substantially, which again results in the expansion of demand. In a situation where the supply does not react elastically to the expansion of liquidity, the current account becomes a reflection of internal overheating. The reason why the issue does not elastically react to financial factors such as demand suggests a clear overestimation of the supply's elasticity and the failure to take into account the fundamental constraints of the sustainable growth trajectory. In addition, the existence of relative restrictions on new investment offers does not exclude the expansion of opportunities for unproductive consumption. The real estate market is a typical example of a concentration of credit, followed by a price boom and the emergence of income effects that further increase the demand for real estate and provide further expansion of consumption.

Thirdly, changing the attitude to risk and the emergence of competition based on risk, and not based on the cost of borrowing make the financial boom extremely vulnerable to the quality of institutions. In addition, the link «liquidity attitude to risk» becomes a strong driver of changing economic behaviour. Offsets towards consumption and reduced propensity to save are also fuelled by speculative motives. This is especially true for the real estate market. The opportunities in the mortgage sector transform the long-term consumption function, while increasing the value of current account fluctuations.

Fourthly, the expectations factor and the credibility of the central banks play an important role in shaping the financial expansion horizon. It is no coincidence that the financial cycle is considerably longer than the business cycle. Irrespective of capital inflows, expectations of future revenues and confidence in the monetary regime create the preconditions for how both borrowers and lenders perceive the ability to optimally increase leverage in a competitive environment. In other words, the presence of strong positive expectations determines perception of the income growth trajectory. Imbalances in such conditions can be considered equilibrium, and the reaction of economic policy to them - absent or weakly expressed. In the event that the imbalance is not seen as a problem and economic policy is focused on traditional variables - inflation, issuance, public 
sector debt, the latter may fall out of focus, while the ease with which the current account deficit is funded may overshadow the clear deterioration of competitiveness.

Extrapolating these considerations onto the CEE countries, especially in the context of the global financial crisis, as well as in the context of intraEuropean imbalances, makes it possible to identify a number of processes that fully correspond to the logic of the macro-financial approach.

First, the CEE countries continue to be in a state of strong real convergence. Reforms aimed at EU membership, and subsequently reforms aimed at adapting to a more severe post-crisis environment, have created a favourable environment for the expectation of persistent income growth. This growth is perceived as an equilibrium trend, as these countries continue to attract real capital, and therefore there is every reason to rely on improving performance of production factors. Institutional reforms also work to increase the efficiency of markets, thereby making economic development more flexible. It is no coincidence that the increase of the real exchange rate in practically all countries of the Eastern region of the EU is seen as an equilibrium trend. Disadvantages of the BalassaSamuelson effect are offset by the capital inflows, and therefore the current account is not a significant limitation of macroeconomic policy. In other words, membership in the EU as a driver of institutional reforms and real convergence create a fundamental basis for expectations regarding the equilibrium nature of personal income growth. This paves the way for financial development.

Secondly, monetary policy reforms, as well as strong institutional foundations of central bank independence, have created a foundation for large-scale disinflation. At the same time, the Balassa-Samuelson effect and the preservation of a substantial amount of nominal inflexibility generate a relatively higher inflationary background than that of the developed countries. Taking into account the equilibrium nature of capital inflows, higher inflation generates pressure to strengthen the real exchange rates. It has several channels of influence on the economies of the region.

A. The current account is under pressure, and the dependence on the inflow of capital is increasing. Changes in the structure of cross-border flows can have a significant effect on financial stability. It is no coincidence that after correction of imbalances after the crisis, reforms and fiscal devaluations, a number of CEE countries have achieved surplus current accounts, which has not been observed for more than a decade.

$B$. The real increase in exchange rate accelerates real convergence, especially when the first and second trends are equilibrium and do not cause the opposite considerations of economic agents, and economic policy assures the latter that these processes will not hinder a significant deviation from sustainable growth. Naturally, this improves the ability to borrow, and lenders become more confident in the future solvency of borrowers. Equilibrium real convergence en- 

experience of financial imbalances, proactivity or protective reaction

courages financial deepening, but does not guarantee that loan expansion will not turn into a boom with correlated inflation of asset prices. In case of positive coincidence, the strengthening of the real exchange rate acts as a financial accelerator, resulting in the heating of the financial sector.

C. Along with the strengthening of the real exchange rate, the nominal strengthening (or immutability in terms of fixing) of national currencies is a direct consequence of the large inflow of capital, as well as attempts of central banks to prevent the inflationary consequences of the structural surplus of the banking system liquidity. Dollarization of liabilities may seem like the optimal strategy, as the cost of borrowing in foreign currency expressed in yield is reduced in the national currency. At the same time, dollarization strengthens the financial tool of the exchange rate in the transmission mechanism of monetary policy. This shows that price stability allows for a narrowing of incentives to dollarization of assets (hedging the risk of devaluation), while real and nominal strengthening of the rate encourages dollarization of liabilities to minimize alternative costs. Along with favourable global financial conditions, the equilibrium strengthening of the rate becomes an important element in the mechanics of financial expansion at least, if not its detonator.

The level of dollarization in the CEE countries remains quite contrasted, but generally somewhat higher than in other regions. For example, the share of dollarized deposits in Bulgaria reaches $50 \%$, with loans at $56 \%$, in Croatia $63 \%$ and $72 \%$ respectively, in Estonia $79 \%$ and $35 \%$, in Hungary $-57 \%$ and $21 \%$, in Latvia $-88 \%$ and $45 \%$, in Lithuania $56 \%$ and $47 \%$, in Romania $55 \%$ and $50 \%$, in Slovenia $46 \%$ and $37 \%$, in Serbia $75 \%$ and $45 \%$, while in the Czech Republic $12 \%$ and $13 \%$, in Poland $-25 \%$ and $19 \%$, in Slovakia - $18 \%$ and $20 \%$. The level of dollarization in general can explain the intensity of macroprudential regulation $^{26}$. However, in the case of countries such as the Czech Republic, the monetary regime is more effective in securing macroeconomic stability.

Thirdly, the financial integration of the new EU members and its neighbours opened the door for a significant cross-border influx of bank capital. One of the principal channels for the expansion of global banks was participation in capital. The significant role of leading world banking groups has led to a dramatic improvement in access to credit, as well as increased risk-based competition. At the same time, the majority of cross-border influx of bank capital concentrated on lending for the purchase of residential real estate. For example, in the pre-crisis decade, the capital inflow into the banking sector in\% of GDP in the Czech Republic amounted to $14 \%$ in 2008 , and housing loans accounted to $15 \%$, in Poland $-17 \%$ and $13 \%$ respectively, in Bulgaria $-18 \%$ and $12 \%$, in Roma-

${ }^{26}$ Dumicic, M. Macroprudential Policy in Central and Eastern European Countries - Is There Something We Should Learn? / M. Dumicic // The Twentieth Dubrovnik Economic Conference, Dubrovnik, June 11-13, 2014. Organized by Croatian National Bank. - Dubrovnik, 2014. - P. 23. 
nia $-24 \%$ and $4 \%$, in Slovakia $-22 \%$ and $13 \%$, in Hungary $-26 \%$ and $14 \%$, in Slovenia - 38\% and 10\%, in Lithuania - 41\% and $16 \%$, in Estonia $-40 \%$ and $37 \%$, in Latvia $-54 \%$ and $30 \%{ }^{27}$. Excepting Bulgaria, differentiation based on the monetary regime is also evident.

Fourth, similarly to other countries in the overcoming phase of real convergence, the real estate market was rather sensitive to the inflow of capital and persistent growth of income per person. Thus, in Poland, during the period of $1990-2001$, the average annual growth of residential property prices was $9.1 \%$, while for the period of $2002-2007$ it was $2.3 \%$, in Croatia $-2.7 \%$ and $8,7 \%$ respectively, in the Czech Republic - 16.7\% and 9.8\%, in Slovenia - 6.1\% and $9.9 \%$, in Hungary - $8 \%$ and $11.9 \%$, in Bulgaria (since 2001) - 23,5\%, in Lithuania $-4.9 \%$ and $23.8 \%$, in Estonia $-13.8 \%$ and $36.4 \%$. For example, in Germany corresponding price dynamics was $-0.2 \%$ and $0.2 \%$, in the USA $-4.1 \%$ and $7.7 \%$, in Greece $-8.8 \%$ and $8.9 \%$, in Ireland $-14,0 \%$ and $10.6 \%$, in the United Kingdom $-8.2 \%$ and $14.8 \%$, in Portugal $-4.6 \%$ and $1.2 \%$, in Spain $-7.7 \%$ and $18.4 \%{ }^{28}$. We can see that, according to the dynamics of residential property prices, the CEE countries are in the same scale of financial imbalances, as the countries that have suffered from the boom in the real estate market during the 2007-2008 crisis the most. In some cases, the CEE countries even surpass them. At that, the most striking inflation of housing prices was in the countries with a fixed-rate regime: Bulgaria, Lithuania, Latvia and Estonia. A similar tendency is observed for other post-socialist countries. In all cases, the fundamental factors - growth of GDP per capita, demographic situation and real interest rates - played a key role in the price boom in the real estate market. The influx of capital and foreign transfers played the role of price boom amplifier ${ }^{29}$. This once again emphasizes how, in favourable circumstances and without a policy addressing financial imbalances, real convergence can act as a system vulnerability driver.

The above-mentioned inclination of the CEE countries to financial imbalances implies that they should exhibit a characteristic combination of immediate internal and external manifestation. In empirical terms to identify the positioning of a country according to financial imbalances various indicators are elected. For example, external imbalances may be characterized by changes in real effective rates, capital inflows into the financial sector, current account deficits, and internal ones - the dynamics of domestic credit, debt accumulation by the private sector, real long-term interest rates, asset price changes, etc. The example of

\footnotetext{
${ }^{27}$ Composition of Capital Inflows to Central and Eastern Europe (CEE) - is Poland Different? // ECFIN Country Focus. - 2014. - Vol. 11, Is. 8. - Sept. - P. 2.

${ }^{28}$ Egert, B. Determinants of House Prices in Central and Eastern Europe / B. Egert, D. Mihaljek // BIS Working Paper. - 2007. - № 236. P. 1-31.

${ }^{29}$ Stepanyan, V. House Price Determinants in Selected Countries of the Former Soviet Union // V. Stepanyan, T. Poghosyan, A. Bibolov // IMF Working Paper. - 2010. WP/10/104. P. 1-16.
} 

experience of financial imbalances, proactivity or protective reaction

EMU countries has shown that combining the variables of domestic credit and current account in the analysis sufficiently represents the situation with regards to the scale of imbalances. This is especially true of the correlation between imbalance correction and recovery. The improvement of the current account most closely corresponds to the rate of recovery of the economy. Correction of credit imbalances also has a positive effect on the recovery of the economy, albeit it is less pronounced, if compared with the improvement of the current account ${ }^{30}$.

The dynamics of domestic credit directly affects the expansion of consumption and marginal propensity to save, induced by the acquisition of real estate in debt. It is, therefore, a factor of external imbalance. Moreover, the current account indicators to a certain extent serve as evidence of competitiveness. In other words, if the loan focused on unproductive consumption and investment, then the correction depth of the credit market does not inevitably equal automatic benefits of credit compression to restore growth. This is in part due to the lost access to it by those who were planning a real investment. Meanwhile improvement of the current account directly reflects the restoration of competitiveness and elimination of unproductive import drivers. Nevertheless, these two variables characterize the imbalances in the broad sense, and therefore they are chosen for empirical analysis.

The sample of countries includes all post-socialist countries in Europe, except Russia and Albania. It shows fairly convincing evidence proving that financial imbalances were attributable to the vulnerability of the CEE countries until 2008. However, the nature of the variation in the middle of the sample indicates a lack of country homogeneity. At least there is no variation similar to the case of euro zone member-countries. Domestic credit continues to affect the balance of payments, but the sample, like in the first case, lacks homogeneity. In addition, the relationship profile between internal and external imbalances has changed. Despite the absence of rigid counteraction to the dynamics of the current account loans, CEE countries have become less varied in both indicators. Thus, they also significantly differ from the EMU members, where the contrast between the degrees of imbalances accumulation was significantly higher. From this we can conclude that the process of correcting imbalances encompassed the entire region, while in the euro area imbalances were adjusted where they were most evident.

Regarding the correction process, it is empirically defined as «the average for 2004-2008 - the average for 2009-2016 of the corresponding indicator». In other words, a greater difference between the mean values for the periods in question means more intensive correction process, namely: the more negative the current account indicators are, the more positive the internal loan ones will

\footnotetext{
${ }^{30}$ Koziuk, V. V. Correction depth of financial imbalances in the euro area and the problem of recovery growth / V. V. Kozyuk // Journal of the European Economy. - 2017. - Vol. 16, No. 1. - P. 17-40.
} 
be. The existence of a correction, but the nature of the relationship between variables continues to indicate the problem of significant differences in the correction profiles by country. In addition, in Ukraine and Belarus, the external correction has not happened at all. On the contrary, the current account before and after 2008 deteriorated, demonstrating both the inconsistency of the correction and the lack of rigid incentives to change macroeconomic policies to fit a development trajectory that is less susceptible to systemic financial stress. Excluding Ukraine and Belarus from the sample substantially approximates the nature of the connection to the theoretical expectation. Excluding Montenegro as a country with a marginal scope of correction (due to phenomenal deficits and capital inflows into the real estate sector) improves the statistical quality of the approximation function. However, this still does not correspond to the correction experience in the euro area.

Changes in the positions of countries in the imbalance coordinates (Table 3) are also impressive. Table 3 shows the groups of countries divided by the scale of imbalances. In 2004-2008, among countries with significant external imbalances were those, in which the average value of the current account exceeded $5 \%$, and for the period 2009-2016 - 3\%. Some decrease in this value is conditioned by the so-called shifting of the norm (the emergence of a new normality). The tightening regulation of capital flows also indicates that countries may be less unconcerned about external imbalances in post-crisis realities. For the same period, the countries with a significant increase in domestic credit included those, in which the average value amounted to more than $10 \%$ and more than $0 \%$ respectively. According to Table 3, only Serbia, Bosnia and Herzegovina and Belarus stayed in the same quadrant of significant internal and external imbalances.

The change in the position of countries regarding the imbalances coordinates before and after the crisis prompts several conclusions. Most countries affected by the crisis changed their position to almost the opposite one. These are mainly countries with a fixed exchange rate. In its pure form this concerns Bulgaria and the Baltic countries. Poland and the Czech Republic - the most successful inflation combatants - remained in the same quadrant. Slovakia is one of the few countries that has improved its positioning: the current account has relatively decreased, while domestic credit has relatively risen. This could be attributed to the benefits of membership in the euro zone, but in the case of Slovenia, this does not look like a convincing argument. Slovenia experienced a credit boom before the crisis and a significant correction of the credit market after it. Hungary, which also suffered from the crisis, remained in the same quadrant, indicating that the problem of imbalances was not clearly expressed. The external debt of the state and corporate sectors was more stressful than typical regional imbalances. Ukraine's position has worsened. The current account deficit has increased, while the domestic loan has slowed significantly. Apart from the war, this can be explained by the serious lag in structural reforms and poor investment climate, which means that even small demand factors are reflected in a worsening current account balance. 
Table 3

Options of the post-socialist countries for combining external and internal imbalances

\begin{tabular}{|c|c|c|c|}
\hline \multicolumn{4}{|c|}{$2004-2008$} \\
\hline & & \multicolumn{2}{|c|}{ Current account deficit, \% of GDP } \\
\hline & & Less than $5 \%$ & More than $5 \%$ \\
\hline \multirow{2}{*}{$\begin{array}{l}\text { Growth of } \\
\text { domestic } \\
\text { credit to } \\
\text { GDP, \% } \\
\text { per annum }\end{array}$} & $\begin{array}{c}\text { Less than } \\
10 \%\end{array}$ & Hungary & Slovakia, Moldova, Croatia \\
\hline & $\begin{array}{l}\text { More than } \\
10 \%\end{array}$ & $\begin{array}{l}\text { Ukraine, Slovenia, } \\
\text { Czech Republic, } \\
\text { Belarus, Poland }\end{array}$ & $\begin{array}{l}\text { Serbia, Romania, Montene- } \\
\text { gro, Lithuania, Macedonia, } \\
\text { Latvia, Estonia, Bulgaria, } \\
\text { Bosnia and Herzegovina }\end{array}$ \\
\hline \multicolumn{4}{|c|}{$2009-2016$} \\
\hline & & Less than $3 \%$ & More than $3 \%$ \\
\hline \multirow{2}{*}{$\begin{array}{l}\text { Growth of } \\
\text { domestic } \\
\text { credit to } \\
\text { GDP, \% } \\
\text { per annum }\end{array}$} & $\begin{array}{l}\text { Less than } \\
0 \%\end{array}$ & $\begin{array}{c}\text { Slovenia, Romania, } \\
\text { Latvia, Lithuania, Es- } \\
\text { tonia, Bulgaria Hun- } \\
\text { gary } \\
\end{array}$ & $\begin{array}{l}\text { Ukraine, Montenegro, } \\
\text { Moldova }\end{array}$ \\
\hline & $\begin{array}{c}\text { More than } \\
\quad 0 \%\end{array}$ & $\begin{array}{l}\text { Slovakia, Czech Re- } \\
\text { public, Poland, Ma- } \\
\text { cedonia, Croatia }\end{array}$ & $\begin{array}{l}\text { Serbia, Bosnia and Herze- } \\
\text { govina, Belarus }\end{array}$ \\
\hline
\end{tabular}

Source: created according to data of BIS (www.bis.org) and IMF (www.imf.org).

Another conclusion is that membership in the EU (and partly in the euro zone) directly or indirectly creates a more powerful pressure on imbalance correction. Most likely, this pattern should be associated with a stronger competitive environment and a tighter framework for macroeconomic policy. Such a framework requires real structural changes to help the economy adapt to new equilibrium conditions, whereas the profanity of structural change only worsens the situation in the medium term. The possibility of avoiding reforms in the short term may be supported by hidden subsidies or external direct / hidden transfers. The case of deterioration in the positioning of Ukraine and Belarus is quite indicative. However, the doping of a false macroeconomic course quickly fails, and transforming doping into a systemic framework requires changes in the formal or informal status of sovereignty.

Moreover, the adaptation to post-crisis reality has shown the absence of a clear polarization of CEE countries, compared to the case of EMU membercountries. The former as a group were more homogeneous in terms of similar vulnerability drivers, but more heterogeneous in terms of economic policy re- 
gimes, and relevant vulnerability risks. It is also obvious that both in the case of the CEE countries, and in the case of EMU members, correction of imbalances was more painful when the credit expansion was combined with the loss of external competitiveness. This led to the fact that while the launch of fiscal devaluation was effective in terms of results, it also required significant social losses. The case of Slovakia shows that membership in the euro area (in the broader sense a fixed exchange rate) is not always an explanation for a more pronounced vulnerability to fluctuations in global liquidity. The counter-cyclical modality of the mix-policy matters.

Another difference between the CEE countries and EMU is the lack of a convincing link between correction of imbalances and recovery. In the case of the EMU, such a link was traced most clearly to the correction of external deficits. Correction of the credit market correlated with the rate of post-crisis recovery more clearly in the case of the countries most affected by it $^{31}$.

Thus, the absence of the theoretically predicted link between correction of the credit market and recovery after the financial shock of 2007-2009. The exclusion of Ukraine, for which the decrease in loans is partly caused by the armed conflicts and loss of territory, changes the direction of the link, but its density remains extremely low. Likely, despite the fact that the credit expansion before the crisis was present in almost all CEE countries, most of them blurred the line between the healthy deepening of the financial system and the credit bubble. This slowdown in lending had both a negative and positive impact on the recovery in different countries. The correlation between the correction of the payment deficit and the recovery of growth is clearer. Its direction corresponds to the theoretical prediction, despite the weak statistical connection. The weakness of the connection can also be explained by the fact that not all countries have undergone a correction of the payment deficits on a scale that would allow faster growth with a radical improvement of external competitiveness. Admittedly, the structural tendency to the current account deficit continues to be the reason why the correction of the external imbalance is asymmetric in terms of countries. However, in this case, countries with longer experience of fixing rates show better recovery rates, although this is partly a sign of a larger previous downturn.

Nevertheless, the nature of the mix policy is also important. For example, the ability to tailor fiscal consolidation to the needs of restoring global competitiveness is a difficult political task. At the same time, the less pronounced propensity to imbalance corresponds to less varied economic growth. This is a definitive answer to the question of optimal mix policy. If a country relies on a particular policy regime that can minimize macro-financial fluctuations, then changing it or introducing new policy tools may not seem necessary even when others

${ }^{31}$ Козюк В. В. Глибина корекції фрінансових дисбалансів у зоні євро та проблема відновлення зростання / В.В.Козюк // Журнал європейської економіки. - 2017. T. 16, № 1. - C. 17-40. 

experience of financial imbalances, proactivity or protective reaction

are actively pursuing such actions. This statement can be considered a problem of the long-term halt in the enlargement of the euro zone after the accession of the Baltic States, as well as that of ambiguous distribution of macro-prudential regulation in the region.

\section{Intensity of macroprudential instruments use in CEE countries: heterogeneity of the sample or heterogeneity of motive}

CEE countries show a structurally determined propensity to macrofinancial vulnerability. Most of them have been damaged by the spiral of global financial imbalances. It is entirely natural to assume that this experience should be converted into a mix-policy transformation in order to enhance its addressing the cyclical effects of the financial system, which deepens and integrates with global finances.

The data of the European Systemic Risk Board makes it possible to see that most of the new EU members use a set of macroprudential instruments based on Basel III basic requirements (Table 4).

Table 4

Active macroprudential instruments in select CEE countries

\begin{tabular}{|c|l|l|l|c|}
\hline Country & \multicolumn{1}{|c|}{ Instrument } & $\begin{array}{c}\text { Primary } \\
\text { intermediate } \\
\text { goal }\end{array}$ & $\begin{array}{r}\text { Description } \\
\text { of measure }\end{array}$ & Status \\
\hline Bulgaria & $\begin{array}{l}\text { Countercyclical } \\
\text { capital buffer (CCB) }\end{array}$ & $\begin{array}{l}\text { Credit growth } \\
\text { and leverage }\end{array}$ & $\begin{array}{l}\text { Setting of CCB rate at } \\
0 \%\end{array}$ & Active \\
\hline Croatia & $\begin{array}{l}\text { Countercyclical } \\
\text { capital buffer (CCB) }\end{array}$ & $\begin{array}{l}\text { Credit growth } \\
\text { and leverage }\end{array}$ & $\begin{array}{l}\text { Keeping of CCB rate at } \\
0 \%\end{array}$ & Inactive \\
\hline Croatia & $\begin{array}{l}\text { Capital buffer for } \\
\text { systemically impor- } \\
\text { tant institutions (SIls) }\end{array}$ & $\begin{array}{l}\text { Misaligned } \\
\text { incentives }\end{array}$ & $\begin{array}{l}\text { Identification of nine } \\
\text { Slls with corresponding } \\
\text { buffer rates. }\end{array}$ & Active \\
\hline $\begin{array}{c}\text { Czech } \\
\text { Republic }\end{array}$ & $\begin{array}{l}\text { Countercyclical } \\
\text { capital buffer (CCB) }\end{array}$ & $\begin{array}{l}\text { Credit growth } \\
\text { and leverage }\end{array}$ & $\begin{array}{l}\text { Keeping of CCB rate at } \\
0-0,5 \%\end{array}$ & $\begin{array}{c}\text { Not any- } \\
\text { more active }\end{array}$ \\
\hline $\begin{array}{c}\text { Czech } \\
\text { Republic }\end{array}$ & $\begin{array}{l}\text { Capital buffer for } \\
\text { systemically impor- } \\
\text { tant institutions (SIls) }\end{array}$ & $\begin{array}{l}\text { Misaligned } \\
\text { incentives }\end{array}$ & $\begin{array}{l}\text { ldentification of seven } \\
\text { Slls with corresponding } \\
\text { buffer rates. }\end{array}$ & Active \\
\hline
\end{tabular}


ISSN 2519-4070

\begin{tabular}{|c|c|c|c|c|}
\hline Country & Instrument & $\begin{array}{c}\text { Primary } \\
\text { intermediate } \\
\text { goal } \\
\end{array}$ & $\begin{array}{l}\text { Description } \\
\text { of measure }\end{array}$ & Status \\
\hline $\begin{array}{l}\text { Czech } \\
\text { Republic }\end{array}$ & LTV & $\begin{array}{l}\text { Credit growth } \\
\text { and leverage }\end{array}$ & $\begin{array}{l}\text { LTV }>90 \% \text { for residen- } \\
\text { tial mortgage loans, } \\
\text { LTV }>100 \% \text { for other } \\
\text { mortgage loans }\end{array}$ & Active \\
\hline Estonia & $\begin{array}{l}\text { Countercyclical } \\
\text { capital buffer (CCB) }\end{array}$ & $\begin{array}{l}\text { Credit growth } \\
\text { and leverage }\end{array}$ & $\begin{array}{l}\text { Setting of CCB rate at } \\
0 \%\end{array}$ & Active \\
\hline Hungary & $\begin{array}{l}\text { Countercyclical } \\
\text { capital buffer (CCB) }\end{array}$ & $\begin{array}{l}\text { Credit growth } \\
\text { and leverage }\end{array}$ & $\begin{array}{l}\text { Setting of CCB rate at } \\
0 \%\end{array}$ & Active \\
\hline Hungary & $\begin{array}{l}\text { Capital buffer for } \\
\text { systemically impor- } \\
\text { tant institutions (SIls) }\end{array}$ & $\begin{array}{l}\text { Misaligned } \\
\text { incentives }\end{array}$ & $\begin{array}{l}\text { Identification of nine } \\
\text { Slls with corresponding } \\
\text { buffer rates. }\end{array}$ & Active \\
\hline Hungary & Liquidity ratio & $\begin{array}{l}\text { Maturity mis- } \\
\text { match and } \\
\text { market liquid- } \\
\text { ity }\end{array}$ & $\begin{array}{l}\text { Changing the set of arti- } \\
\text { cles that fall under the } \\
\text { definition of the instru- } \\
\text { ment and the institutions } \\
\text { that must comply with it }\end{array}$ & $\begin{array}{l}\text { Some ele- } \\
\text { ments are } \\
\text { active, } \\
\text { some- } \\
\text { planned }\end{array}$ \\
\hline Hungary & Systemic risk buffer & $\begin{array}{l}\text { Credit growth } \\
\text { and leverage }\end{array}$ & $\begin{array}{l}\text { Institution-specific sys- } \\
\text { temic risk buffer set in } \\
\text { the range of } 0 \% \text { to } 2 \%\end{array}$ & $\begin{array}{l}\text { Not yet ac- } \\
\text { tive }\end{array}$ \\
\hline Latvia & $\begin{array}{l}\text { Countercyclical } \\
\text { capital buffer (CCB) }\end{array}$ & $\begin{array}{l}\text { Credit growth } \\
\text { and leverage }\end{array}$ & $\begin{array}{l}\text { Setting of CCB rate at } \\
0 \%\end{array}$ & $\begin{array}{l}\text { Not yet ac- } \\
\text { tive }\end{array}$ \\
\hline Latvia & $\begin{array}{l}\text { Capital buffer for } \\
\text { systemically impor- } \\
\text { tant institutions (SIls) }\end{array}$ & $\begin{array}{l}\text { Misaligned } \\
\text { incentives }\end{array}$ & $\begin{array}{l}\text { Identification of six SIls } \\
\text { with corresponding } \\
\text { buffer rates. }\end{array}$ & Active \\
\hline Lithuania & $\begin{array}{l}\text { Countercyclical } \\
\text { capital buffer (CCB) }\end{array}$ & $\begin{array}{l}\text { Credit growth } \\
\text { and leverage }\end{array}$ & $\begin{array}{l}\text { Setting of CCB rate at } \\
0 \%\end{array}$ & Active \\
\hline Lithuania & $\begin{array}{l}\text { Capital buffer for } \\
\text { systemically impor- } \\
\text { tant institutions (SIIs) }\end{array}$ & $\begin{array}{l}\text { Misaligned } \\
\text { incentives }\end{array}$ & $\begin{array}{l}\text { Identification of four SIIs } \\
\text { with corresponding } \\
\text { buffer rates. }\end{array}$ & Active \\
\hline Lithuania & DSTI & $\begin{array}{l}\text { Credit growth } \\
\text { and leverage }\end{array}$ & $\begin{array}{l}\text { DSTI of not more than } \\
50 \% \text { of borrower's net in- } \\
\text { come when an interest } \\
\text { rate of at least } 5 \% \text { is } \\
\text { used for the calculations }\end{array}$ & Active \\
\hline Lithuania & Liquidity ratio & $\begin{array}{l}\text { Maturity mis- } \\
\text { match and } \\
\text { market liquidity }\end{array}$ & $100 \%$ & Active \\
\hline Poland & $\begin{array}{l}\text { Countercyclical } \\
\text { capital buffer (CCB) }\end{array}$ & $\begin{array}{l}\text { Credit growth } \\
\text { and leverage }\end{array}$ & $\begin{array}{l}\text { Setting of CCB rate at } \\
0 \%\end{array}$ & Active \\
\hline Poland & $\begin{array}{l}\text { Capital conserva- } \\
\text { tion buffer }\end{array}$ & $\begin{array}{l}\text { Credit growth } \\
\text { and leverage }\end{array}$ & $\begin{array}{l}\text { Buffer rate between } \\
1,25-1,875 \%\end{array}$ & Active \\
\hline Romania & $\begin{array}{l}\text { Countercyclical } \\
\text { capital buffer (CCB) }\end{array}$ & $\begin{array}{l}\text { Credit growth } \\
\text { and leverage }\end{array}$ & $\begin{array}{l}\text { Setting of CCB rate at } \\
0 \%\end{array}$ & Active \\
\hline Romania & $\begin{array}{l}\text { Capital conserva- } \\
\text { tion buffer }\end{array}$ & $\begin{array}{l}\text { Credit growth } \\
\text { and leverage }\end{array}$ & 32016 p. $0,625 \%$ & Active \\
\hline
\end{tabular}


Macroprudential regulation in countries of Central and Eastern Europe: experience of financial imbalances, proactivity or protective reaction

\begin{tabular}{|c|c|c|c|c|}
\hline Country & Instrument & $\begin{array}{c}\text { Primary } \\
\text { intermediate } \\
\text { goal }\end{array}$ & $\begin{array}{l}\text { Description } \\
\text { of measure }\end{array}$ & Status \\
\hline Romania & $\begin{array}{l}\text { Capital buffer for } \\
\text { systemically impor- } \\
\text { tant institutions (SIls) }\end{array}$ & $\begin{array}{l}\text { Misaligned } \\
\text { incentives }\end{array}$ & $\begin{array}{l}\text { Identification of nine } \\
\text { Slls with corresponding } \\
\text { buffer rates. }\end{array}$ & Active \\
\hline Romania & Systemic risk buffer & $\begin{array}{l}\text { Credit growth } \\
\text { and leverage }\end{array}$ & In development & $\begin{array}{l}\text { Not yet ac- } \\
\text { tive }\end{array}$ \\
\hline Slovakia & $\begin{array}{l}\text { Countercyclical } \\
\text { capital buffer (CCB) }\end{array}$ & $\begin{array}{l}\text { Credit growth } \\
\text { and leverage }\end{array}$ & $\begin{array}{l}\text { Setting of CCB rate at } \\
0 \%\end{array}$ & Active \\
\hline Slovakia & Systemic risk buffer & $\begin{array}{l}\text { Credit growth } \\
\text { and leverage }\end{array}$ & $\begin{array}{l}\text { Does not apply to small } \\
\text { and medium-sized in- } \\
\text { vestment companies }\end{array}$ & Active \\
\hline Slovakia & $\begin{array}{l}\text { Capital buffer for } \\
\text { systemically impor- } \\
\text { tant institutions (SIls) }\end{array}$ & $\begin{array}{l}\text { Misaligned } \\
\text { incentives }\end{array}$ & $\begin{array}{l}\text { Identification of five SIIs } \\
\text { with corresponding } \\
\text { buffer rates. }\end{array}$ & Active \\
\hline Slovenia & $\begin{array}{l}\text { Countercyclical } \\
\text { capital buffer (CCB) }\end{array}$ & $\begin{array}{l}\text { Credit growth } \\
\text { and leverage }\end{array}$ & $\begin{array}{l}\text { Setting of CCB rate at } \\
0 \%\end{array}$ & Active \\
\hline Slovenia & $\begin{array}{l}\text { Capital buffer for } \\
\text { systemically impor- } \\
\text { tant institutions (SIIs) }\end{array}$ & $\begin{array}{l}\text { Misaligned } \\
\text { incentives }\end{array}$ & $\begin{array}{l}\text { Identification of eight } \\
\text { Slls with corresponding } \\
\text { buffer rates. }\end{array}$ & Active \\
\hline Slovenia & Systemic risk buffer & $\begin{array}{l}\text { Credit growth } \\
\text { and leverage }\end{array}$ & $\begin{array}{l}\text { Applies to systemically } \\
\text { important banks for posi- } \\
\text { tions open in operations } \\
\text { with residents; } 0 \% \text { from } \\
2016,1 \% \text { from } 2017\end{array}$ & Active \\
\hline
\end{tabular}

Source: European Systemic Risk Board. A Review of Macroprudential Policy in the EU. 2015-2016 [WWW resource]. - Access: www.esrb.europa.eu.

The use of mostly macroprudential tools embedded in capital requirements under Basel III indicates that CEE countries are less exposed to the reoccurring risks of global liquidity expansion than before the crisis. Often the type of instrument used indicates a degree of restraint in comparison with a number of countries that have suffered during the European crisis of imbalance correction. A slow recovery in the financial sector in Europe has also played a role, but the prolonged maintenance of low interest rates in the euro area is likely to be a long-term pressure factor on the reactivation of macro-financial vulnerabilities in the CEE countries.

However, there is a certain gap in the identification of the macroprudential instruments use. On the one hand, there is a formal procedure for activation of instruments in the EU, which is fixed by the European Systemic Risk Board. On the other hand, there is a long-standing experience of using monetary policy instruments, regulation of capital flows, banking regulation, etc. with macropruden- 
tial objectives in mind. In light of this, the formal and actual intensity of the application of these tools may differ. In the case of CEE, along with the eventual analysis (Table 4) of introducing macroprudential instruments, the empirical approach paints a slightly different picture.

One approach to assessing the intensity of macroprudential policy implementation is the macroprudential policy index (MPI) calculated for 119 countries. This index reflects the extent to which countries apply (already activate) 12 out of 18 different tools, as reflected in Global Macroprudential Policy Instruments review. The quantitative score is determined by assigning each tool a value of « 1 », if applicable, and " 0 », if not. The values obtained are summed up. The maximum value of the MPI is $12^{32}$. Based on the grouping, we can see that the CEE countries do not differ in their active use of macroprudential instruments (see Table 5).

Table 5

Macroprudential policy Index by groups of countries, average values

\begin{tabular}{|l|c|c|c|c|}
\hline & 2002 & 2007 & 2012 & 2013 \\
\hline All countries (119 countries) & 1,4 & 1,7 & 2,3 & 2,5 \\
\hline $\begin{array}{l}\text { Countries with emerging markets, commodity } \\
\text { exporters (29 countries) }\end{array}$ & 2,1 & 2,6 & 3,0 & 3,1 \\
\hline $\begin{array}{l}\text { Developed countries rich in resources } \\
\text { (4 countries) }\end{array}$ & 1,3 & 1,3 & 2,3 & 2,8 \\
\hline Countries targeting inflation (27 countries) & 1,5 & 2,0 & 3,0 & 3,2 \\
\hline CEE countries (18 countries) & 0,72 & 1,44 & 2,3 & 2,28 \\
\hline CEE countries targeting inflation (5 countries) & 0,4 & 1,8 & 3,4 & 3,2 \\
\hline
\end{tabular}

Notes: 1 . The macroprudential policy index is calculated for 119 countries.

2. Countries with emerging markets that are commodity exporters are defined by the IMF. Their total number is 52. The macroprudential policy index is calculated for 29 of them. Developed countries rich in resources are Norway, Canada, Australia, and New Zealand. Countries targeting inflation are determined by the IMF.

3. CEE countries selected for grouping: Ukraine, Estonia, Latvia, Lithuania, Poland, Slovakia, Hungary, Slovenia, Croatia, Serbia, Bulgaria, Bosnia and Herzegovina, Macedonia, Montenegro, Czech Republic, Romania, Moldova, Belarus.

Source: Cerutti E. The Use and Effectiveness of Macroprudential Policies: New Evidence / E. Cerutti, S. Claessens, L. Laeven // IMF Working Paper. - 2015. - WP/15/61. - P. 3739.

${ }^{32}$ Cerutti E. The Use and Effectiveness of Macroprudential Policies: New Evidence / E. Cerutti, S. Claessens, L. Laeven // IMF Working Paper. - 2015. - WP/15/61 - P. 6. 

experience of financial imbalances, proactivity or protective reaction

The conducted grouping makes it possible to see that CEE countries are less active in activating macroprudential instruments than on average all countries covered by the calculation of the index. Even though the general tendency to increase the value of macroprudential policies is present in post-socialist countries, they are significantly behind, for example, resource-rich countries with high macrofinancial risks. It is also noticeable that countries targeting inflation are more interested in strengthening policies aimed at financial stability. However, the CEE inflation targets did not follow this trend initially, which is proven by several other studies ${ }^{33}$. Nevertheless, later they show much better results than the average group of CEE countries in general. Although this situation can likely be explained by the fact that in a small sample, the MPI for Romania and Hungary significantly affects the displacement of the result.

Among drivers of the intensity of macroprudential instruments use in the case of CEE countries are: the depth of the financial system (domestic credit to GDP), dollarization rate, GDP per capita, exchange rate regime, capital inflows (\% of GDP), balance of payments, trade openness, etc. Most of the indicators selected to explain the propensity to use macroprudential regulation theoretically predictably correlate, to some extent, with a variable that quantifies the intensity of the instrument use ${ }^{34}$. However, previous studies focused on 9 countries of the $\mathrm{CEE}$, and the selected variable was the quantitative intensity indicator, which was obtained on the basis of direct polling of central bank functionaries ${ }^{35}$.

Despite the convincing results of this kind of research, there are concerns about the limited sampling. In order to obtain new results in this area, it is proposed to expand the sample to 18 countries (see the note to Table 5.4), as well as to change the set of structural variables. In particular, instead of the indicator of capital flows, the Chinn-Ito index is used, which indicates the regime of regulating capital flows. Similarly, in order to analyse the relationship between the experience of imbalances and their corrections, it is suggested that corresponding indicators be used as independent variables. Consequently, the following variables are used to construct a multifactor regression:

$$
\text { y - Macroprudential Policy Index }{ }^{36} \text {; }
$$

\footnotetext{
${ }^{33}$ Dumicic, M. Macroprudential Policy in Central and Eastern European Countries - Is There Something We Should Learn? / M. Dumicic // The Twentieth Dubrovnik Economic Conference, Dubrovnik, June 11-13, 2014. Organized by Croatian National Bank.. - Dubrovnik, 2014. - P. 1-50; Dumicic M. Effectiveness of Macroprudential Policies in Central and Eastern European Countries / M. Dumicic // Croatian National Bank Working Paper. 2017. - W-48. - P. 1-27.

${ }^{34}$ See above.

${ }^{35}$ The results of this survey and their analysis are presented in: Lim C. Macroprudential Policy: What Instruments and How to Use Them? Lessons from Country Experience / C. Lim, F. Columba, A. Costa [et al.] // IMF Working Paper. - 2011. - WP/11/238. - P. 1-81.

${ }^{36}$ Source: Cerutti, E. The Use and Effectiveness of Macroprudential Policies: New Evidence / E. Cerutti, S. Claessens, L. Laeven // IMF Working Paper. - 2015. - WP/15/61. - P. 37-39.
} 
X1 - share of raw material exports (source: World Bank data, www.worldbank.org). Despite the fact that CEE countries do not have significant raw material wealth, the structure of exports has a significant impact on macrofinancial stability, depending on how the shock of the trade conditions is transmitted to financial stability through mediation or exchange rate (if it is flexible) or pressure on the foreign exchange market (when it is fixed). This means that macro-prudential instruments can take on some of their responsibilities, for example, because the positive shock of trading conditions, caused by rising commodity prices, affects the heating of the financial sector and, accordingly, increases its vulnerability. The flexibility of the exchange rate does not always compensate for such a shock if risk tolerance prevails. Theoretically, the higher the raw material dependence of exports, the more inclined the country is to actively use macroprudential regulation;

X2 - Chinn-Ito index (source: The Chinn-Ito Financial Openness Index at http://web.pdx.edu/ ito/Chinn-Ito_website.htm). Unlike the balance of payments indicators, this indicator shows the nature of the regime of capital flows, and not their absolute or relative value. In fact, it reflects the elasticity with which capital can be transported across borders and is neutral to the phases of the global financial cycle. Theoretically, the more liberal is the regime for regulating the movement of capital and, accordingly, the more vulnerable the country is to the fact that cross-border flows increase the pro-cyclicality of the financial system, the more intense is the use of macroprudential systems;

X3 - quantitative indicator of the exchange rate regime (source: IMF classifier, www.imf.org). This variable changes in the range from 0 (fully fixed rate) to 4 (fully floating rate). There is no unanimous answer as to which direction this variable should be with regards to MPI. As a rule, if the exchange rate regime provides for less flexibility, then the vulnerability of the country to macro-financial shocks is intensifying, which opens the door for more active macro-prudential regulation. However, along with this, the floating rate is accompanied by a monetary mode of inflation targeting, which, supported by a more active macroprudential approach, may show a better focus on the issues of minimizing inflation and GDP, as financial stability would be addressed by a «specialized» instrument;

X4 - domestic credit, \% of GDP (Source: World Bank data, www.worldbank.org). In fact, this indicator is a measure of the depth of the financial system. Theoretically, if the financial system is more developed, it is more likely to be a source of shocks, and therefore, macroprudential regulation should be more widespread where there is a higher stage of financial development. On the other hand, a more sophisticated financial system can better cope with shocks, and capital flows are less capable of shattering the financial market. At the same time, the specificity of macroprudential instruments implies that they are activated to neutralize the pro-cyclicality of the financial system and its propensity to concentrate risks, so its ability to compensate for shocks of nonfinancial origin should not be taken into account in this context.; 

experience of financial imbalances, proactivity or protective reaction

X5 - growth of domestic credit, average for 2004-2008 (Source: World Bank data, www.worldbank.org). This indicator will reflect how vulnerable the economy was to the accumulation of internal financial imbalances. Accordingly, if negative experience of vulnerability to imbalances is expressed more clearly, the macroprudential approach should be more active ass well;

X6 - indicator of correction of imbalances (see explanation above). The scale of correction will also show how vulnerable a country turned out to be to the problem of imbalances. Accordingly, the larger the scale of the correction, the more likely it is that the country will take into account such experience;

X7 - Government Efficiency Index (Source: World Bank data, www.worldbank.org). Theoretically, it can be predicted that the introduction of a new «specialized» policy aimed at financial stability largely depends on the quality of governance in the country. Human and social capital in economic policy is often crucial to explain how economic policy instruments will be applied. On the other hand, the effectiveness of governance may not provide for the active use of macroprudential instruments, given that the country will be more resistant to systemic stress, due to the fact that it will effectively operate economic policy instruments in other areas;

X8 - economic growth, average for 2010-2015 (source: IMF data, www.imf.org). It can be assumed that countries that were more successful in overcoming the effects of the global financial crisis or less vulnerable to it will need the macroprudential instruments less. In other words, the more successful economic situation, the less appealing such instruments are. However, higher growth does not always indicate whether they will be more stable in the medium term and whether the role of macro-financial factors of systemic vulnerability will increase as a result of a reassessment of the economic prospects.

The results of the regression analysis (Table 6) continue to confirm the confusing conclusions on the intensity of the macroprudential instruments use in the CEE countries.

Thus, the parameters of the regression equation (Table 6) indicate an acceptable level of statistical significance of the results obtained. However, the values of coefficients with independent variables do not fully correspond to the theoretically predicted results, requiring additional explanations. First, the most significant variables are those that reflect the exchange rate regime (X3), the capital flow regime (X2) and the post-crisis growth (X8). The least significant was the variable characterizing the financial depth $(X 4)$. Secondly, two indicators characterizing the experience of internal financial imbalances appeared to be in the opposite directions with approximately identical significance. The credit expansion before the crisis had an inverse effect on the introduction of macroprudential instruments (X5), while the scale of the correction of the credit market influenced it directly (X6). Thirdly, the export structure variable (X1) is in a predictable, albeit weak connection with MPI. Fourthly, the government efficiency index (X7) is in 
the inverse relation, indicating that macro-prudential regulation is a compensation for a «less efficient government». This hypothesis is confirmed by the relatively strong inverse relationship between the intensity of introducing macroprudential instruments and the rate of post-crisis growth (X8).

Table 6

Parameters of the regression equation (sample of 18 countries, IRI index as a dependent variable)

\begin{tabular}{|c|c|c|c|c|}
\hline & $\mathrm{b}$ & Std. err. of $\mathrm{b}$ & $\mathrm{t}(9)$ & $\mathrm{p}$-value \\
\hline $\mathrm{X} 1$ & 0,03122 & 0,04893 & 0,63817 & 0,539261 \\
\hline $\mathrm{X} 2$ & 0,62459 & 0,37351 & 1,67222 & 0,128811 \\
\hline $\mathrm{X} 3$ & 0,72117 & 0,27841 & 2,59030 & 0,029199 \\
\hline $\mathrm{X} 4$ & $-0,00263$ & 0,02013 & $-0,13043$ & 0,899096 \\
\hline $\mathrm{X} 5$ & $-0,09198$ & 0,12678 & $-0,72546$ & 0,486605 \\
\hline $\mathrm{X} 6$ & 0,08017 & 0,10792 & 0,74281 & 0,476539 \\
\hline $\mathrm{X} 7$ & $-0,04909$ & 0,03326 & $-1,47602$ & 0,174048 \\
\hline $\mathrm{X} 8$ & $-0,18442$ & 0,29692 & $-0,62110$ & 0,549939 \\
\hline $\mathrm{R}^{2}=0,67$ & $\mathrm{~F}(8,9)=2,3105$ & $\mathrm{p}<0,11699$ & Std. err. 1,3435 \\
\hline
\end{tabular}

Note. Obtained using the STATISTICA software package.

Based on the nature of the relationship between variables of regression model, several more generalized aspects have been determined:

A. CEE countries are fairly fragmented in terms of the spread of macroprudential practices. This conclusion is to some extent concurrent with previous considerations. It is possible that contrasting monetary regimes and, accordingly, differences in their intended purpose and effectiveness significantly affect the profile of the macroprudential instruments use.

B. Despite the structural vulnerability to the problem of macro-financial imbalances, as well as the ambiguous experience of their correction, the variables that characterize them do not show significant importance. In other words, the experience of imbalances has not turned out to be a critically important factor in the more intensive use of macroprudential regulation. It can be argued that the important parts are not the imbalances, but the overall macroeconomic weakness, in which financial imbalances are a separate aspect of the structural vulnerability of the economy. 

experience of financial imbalances, proactivity or protective reaction

C. The nominal division of variables into those that characterize the positive and negative nature (not direction) of relationships allows one to distinguish two fundamentally different motives for the introduction of macroprudential regulation.

For the additional testing of the obtained results, the same independent variables were used, but the dependent variable was changed into an indicator that describes the intensity of macroprudential instruments use, as calculated by Lim et al $(2013)^{37}$. Given the relatively smaller number of countries, the sample consists of 11 countries included in the preliminary sample of 18 (minus Ukraine, Belarus, Moldova, Montenegro, Bosnia and Herzegovina, Macedonia and Slovenia). Table 5.7 shows the results of regression analysis and also indicates that in general the patterns found for a larger sample with the MPI as an independent variable are almost entirely confirmed.

Table 7

Parameters of the regression equation (sample of 11 countries, quantitative indicator of estimating the intensity of macroprudential instruments use as a dependent variable)

\begin{tabular}{|c|c|c|c|c|}
\hline & $\mathrm{b}$ & Std. err. of b & $\mathrm{t}(2)$ & $\mathrm{p}$-value \\
\hline $\mathrm{X} 1$ & 0,6332 & 2,1061 & 0,300636 & 0,792065 \\
\hline $\mathrm{X} 2$ & $-1,6406$ & 9,1951 & $-0,178424$ & 0,874827 \\
\hline $\mathrm{X} 3$ & 1,4697 & 9,3421 & 0,157318 & 0,889441 \\
\hline $\mathrm{X} 4$ & 0,1293 & 0,3379 & 0,382770 & 0,738741 \\
\hline $\mathrm{X} 5$ & $-0,8939$ & 1,4875 & $-0,600949$ & 0,608910 \\
\hline $\mathrm{X} 6$ & 0,8175 & 1,7299 & 0,472576 & 0,683066 \\
\hline $\mathrm{X} 7$ & $-0,4487$ & 0,6126 & $-0,732441$ & 0,540106 \\
\hline $\mathrm{X} 8$ & $-1,8789$ & 7,7484 & $-0,242489$ & 0,831001 \\
\hline $\mathrm{R}^{2}=0,84$ & $\mathrm{~F}(8,2)=1,2800$ & $\mathrm{p}<0,51014$ & Std. err. 8,9787 \\
\hline
\end{tabular}

Note. Obtained using the STATISTICA software package.

Data in Table 7 indicate the relative quality of the statistical properties of the model (they are somewhat worse than those presented in Table 6), although the values of the coefficients with independent variables indicate the permissibility of the estimates that will be made on their basis. It has confirmed the direction of rela-

${ }^{37}$ Lim, C. Macroprudential Policy: What Instruments and How to Use Them? Lessons from Country Experience / C. Lim, F. Columba, A. Costa [et al.] // IMF Working Paper. 2011. - WP/11/238. - P. 1-81. 
tionship determined in the previous model for all variables, except the one characterizing the capital flow regime (direct according to the data of Table 6 and inverse according to the data of Table 7), and the variable characterizing the credit depth. However, in the latter case, the value of the coefficient is the lowest possible as, in fact, in the previous case. This indicates that, most likely, financial development does not have a significant effect on the intensity of the introduction of macroprudential instruments. The inverse relationship between the variable X2 and the dependent variable indicates that such instruments are introduced by countries more inclined to regulate capital flows. The difference in the direction of relationship between the two samples can be explained by the fact that in the second case, the proportion of countries with more regulated capital flows is lesser. As for other independent variables, the relative magnitude of the corresponding coefficient and direction of relationship are practically identical in the two models. Consequently, the conclusions drawn from the regression analysis of the first sample are valid for the second sample, and vice versa. This allows us to make some generalizations, taking into account that the direction of relationship with the variable characterizing the flow of capital can be interpreted in both directions.

On the one hand, active implementation of the instruments is more likely to occur where there is a more flexible exchange rate and more liberal regulation of capital flows, indicating that countries take into account the risks of global financial shocks or attempt to make the inflation targeting more flexible. It also means that such a motive will dominate the most successful CEE countries. Effective monetary regimes, low vulnerability to imbalances in the past and more stable growth are characteristic features of such success.

On the other hand, the active introduction of macroprudential instruments is more likely in less successful and more vulnerable economies, which in reality are not as capable of supporting a liberal capital regime or a fixed exchange rate in the form of entry into the euro zone. The higher share of commodity exports, a less profound financial system, lower government efficiency and slower postcrisis growth are characteristic of such countries. Indeed, it is a situation where macroprudential policies are seen as an additional tool for controlling risks generated by overall structural weaknesses and macroeconomic instability. This will be subject to tighter control over capital flows.

In other words, in the first case, the more active introduction of macroprudential instruments will be «offensive» or proactive, whereas in the second case a protective reaction to the general weakness of the economy. Despite the stronger linkage between variables within the framework of the first motive, there is a more complex problem of separating the more successful pro-active countries from countries that do not require intensive use of macroprudential instruments. In the second case, vulnerable countries with protective reactions may be less homogeneous (as evidenced by a weaker bond between dependent and corresponding independent variables), but their vulnerability will be more idiosyncratic. 

experience of financial imbalances, proactivity or protective reaction

It follows that macroprudential policy cannot replace the overall effectiveness of structural reforms designed to strengthen the economy and eliminate the preconditions for pro-cyclicality, in particular, due to the weakness of politics. However, this does not mean that it should not be seen as an important stepping-stone in building a new mixed-policy model focused on strengthening the role of financial stability.

CEE countries have demonstrated a structural vulnerability to systemic financial shocks for a long time. A lower stage of real convergence, expectations of rising income in the future, pressure on the real exchange rate growth, etc. create a favourable basis for the inflow of capital and foreign currency borrowings. Relatively primitive financial systems, the significant role of foreign bank capital and the sensitivity of the asset market to the liquidity expansion increase the risks of relatively rapid transformation of financial development impulses to spiralling financial imbalances. Nevertheless, the CEE countries remain fairly contrasting in terms of monetary regimes, resulting in a significant change in the role of the exchange rate as a factor and channel for the actualization of macro-financial risks.

Despite the structural propensity toward financial imbalances, CEE countries are not as polarized as Eurozone countries, but also not as homogeneous in macrofinancial risks. Despite this, the process of imbalances correction did happen in the region, although it was not as pronounced as in the euro area. Nonetheless, EU membership has unequivocally created a prerequisite for a tougher competitive environment, which has led, in the majority of the new EU Member States, to greater imbalance corrections than other post-socialist countries. However, the countries with floating rate were less affected by this problem than fixed-rate countries (with the exception of Slovakia).

Vulnerability to systemic risks and potential conflicts between price, financial and exchange rate stability should pave the way for a more active transition to macroprudential practices in the region. Empirical studies indicate that there is a certain correlation between the macroeconomic characteristics of the CEE countries and the intensity of the introduction of macroprudential instruments. However, the use of the MPI has shown that CEE countries are not as active in the application of macroprudential regulation, as would be expected. Regression analysis has shown that this group of countries can be nominally divided: more successful countries are offensively introducing macroprudential instruments, that is, they proactively maintain macro-financial stability; less successful countries implement them with a protective purpose, as they are more vulnerable to shocks of capital flows or exchange rate destabilization. This indicates that the overall more successful economic policy, in particular the effectiveness of the monetary regime, creates better conditions for financial stability than an active specialized policy aimed at financial stability. However, the spread of macroprudential practices also does not exclude the extent to which bodies responsible for financial stability are «prone to novelty», indicating the importance of the quality of institutions and human capital. 